\title{
ANNUS MIRABILIS 1989 I JEGO DZIEDZICTWO: SPEŁNIONE OBIETNICE, STRACONE ZŁUDZENIA I NIESPODZIEWANE REZULTATY
}

\section{WSTĘP}

W dwudziestą piąta rocznicę pamiętnego roku 1989 chciałbym przyjrzeć się pewnym aspektom dokonanego wówczas w Polsce historycznego przejścia od komunistycznego ancien régime'u do systemu demokratycznego, przejścia rozciągniętego w czasie, którego kulminacja nastapiła jednak właśnie w 1989 r. Przedmiotem analizy uczynić chciałbym, po pierwsze, sam przebieg ówczesnych wydarzeń, tzn. proces demokratyzacji; po drugie, pewne późniejsze konsekwencje kształtu owego procesu demokratyzacji dla rozwoju wydarzeń w już demokratycznej Polsce; po trzecie wreszcie, sposób, w jaki przebieg owego procesu demokratyzacji jest społecznie pamiętany i oceniany.

Uwzględnienie jednocześnie wszystkich tych trzech kwestii wydaje się o tyle istotne, że społeczne pamiętanie i ocena wydarzeń 1989 r. sa: 1) bardzo zróżnicowane, 2) ewoluujące w czasie, 3) dość chwiejne - te same osoby z różnych przyczyn formułowały i formułują w różnych momentach dość odmienne oceny tych wydarzeń. Te różnice i chwiejność wynikają z dwóch przede wszystkim względów. Postrzeganie wydarzeń 1989 r. dokonuje się przez pryzmat oceny całego ostatniego ćwierćwiecza, blasków i cieni dwudziestu pięciu lat polskiej transformacji, a zwłaszcza jej skutków społecznych i zależy od tego, czy oceny tej dokonuja ,wygrani” czy „przegrani” polskich przemian. Ponadto taka, a nie inna ocena zarówno wydarzeń 1989 r., jak i całego okresu III Rzeczypospolitej stała się istotnym elementem politycznej i medialnej narracji, strategii i retoryki walczacych o wpływy sił politycznych, akcentujących bądź sukcesy i osiagnięcia ostatnich dwudziestu pięciu lat, bądź przeciwnie - ich niedostatki i problemy. Formułowane stanowiska są niejednokrotnie krańcowo odmienne, przy czym wydaje się, że o ile trudno znaleźć całkowicie bezkrytycznych apologetów dokonanych i dokonujących się zmian, o tyle łatwiej natknąc się można na ich totalną krytykę i potępianie w czambuł wszystkiego, co zdarzyło się w Polsce od 1989 r.

Dodatkowa komplikację stwarza fakt, że ta krytyczna ocena wynika z dość różnych przesłanek i dotyczy odmiennych kwestii. Niekiedy jedynie za źródło zła uznaje się tak, a nie inaczej postrzegane wydarzenia z 1989 r. (np. „zmowa elit w Magdalence"); częściej winą - zwłaszcza za kwestie gospodarczo-socjal- 
ne - obarcza się kolejne rządzące już później w Polsce ekipy; niejednokrotnie wreszcie krytyka dotyczy ogólnoświatowych zmian ekonomicznych (globalizacja, przemiany pracy i rynku pracy), bądź wynika z odrzucenia i lęku wobec zachodzących także w całym świecie, a zwłaszcza w cywilizacji zachodniej, przemian rodziny i obyczajowości, postrzeganych jako zagrożenie dla polskiej tożsamości narodowej i tradycyjnych wartości.

\section{O NIEZBĘDNOŚCI ANALIZY PORÓWNAWCZEJ}

Zdając sobie sprawę z owych szerszych uwarunkowań, chciałbym skoncentrować się na analizie samego przebiegu wydarzeń z 1989 r. i lat poprzedzajacych oraz ich dających się uchwycić konsekwencji dla rozwoju sytuacji w Polsce w latach kolejnych. Śledząc debaty na temat tych wydarzeń, ma się często wrażenie, jakoby ich uczestnicy uznawali, że pewne zjawiska, procesy i problemy są specyficzne jedynie dla Polski. Tymczasem olbrzymia większość z nich - dotyczących zarówno uwarunkowań „obiektywnych”, jak i dylematów decyzyjnych stojących przed głównymi aktorami procesu przemian - występowała w olbrzymiej większości krajów, w których dokonywały się procesy demokratyzacji. Wydarzenia w Polsce najlepiej rozważać zatem na szerszym tle porównawczym, pokazując pewne powszechniejsze regularności, a dopiero na tej podstawie ustalać to, co było specyficzne dla Polski.

Podstawowym punktem odniesienia takiej porównawczej analizy jest dla mnie książka Samuela Huntingtona Trzecia fala demokratyzacji, której pierwsze angielskie wydanie ukazało się w $1991 \mathrm{r} .{ }^{1} \mathrm{~W}$ książce tej opisane sa wydarzenia do 1990 r., uwzględnia ona zatem rok 1989 w Polsce (czyli ,proces demokratyzacji”), omawia jednak także porównawczo wyzwania następnego etapu „konsolidacji demokracji”, co także chciałbym wykorzystać.

Zgodnie z argumentami Huntingtona to, co zdarzyło się w Polsce w 1989 r., jest jedynie częścią szerszego, obejmującego różne kontynenty procesu „trzeciej fali demokratyzacji” rozpoczętej rewolucją goździków w Lizbonie w 1975 r., a która to fala do 1990 r. objęła $35 \mathrm{krajów}^{2}$. Samo określenie „trzecia fala demokratyzacji” odnosi się przede wszystkim do procesu politycznego, zmiany systemu sprawowania władzy od reżimu autorytarnego do systemu demokratycznego. W Polsce przybrała formę jednej z trzech wyróżnionych przez Huntingtona postaci, to jest tzw. przemieszczenia (transplacement lub ruptforma) będącego rezultatem „wspólnych działań rządu i ugrupowań opozycyjnych”. Pod czysto politycznym względem polskie przemiany mieszczą się więc w tej samej kategorii co zmiany w Czechosłowacji, Urugwaju, Korei Południowej czy Republice Południowej Afryki, przeciwstawiając się z kolei krajom, w których zmiany wprowadziła głównie dotychczasowa elita rządząca (np. Węgry, Bułgaria, Hiszpania czy Brazylia - jest to tzw. transformacja - transforma-

${ }^{1}$ Korzystam z przekładu polskiego: S. Huntington, Trzecia fala demokratyzacji, Warszawa 2009.

${ }^{2}$ Ibidem, s. 120. 
tion lub reforma), oraz krajom, gdzie demokratyzację przeprowadzały ugrupowania opozycyjne, a reżim autorytarny upadał lub był obalany (np. NRD, Rumunia, Portugalia, Grecja czy Argentyna - jest to z kolei tzw. zastapienie - replacement lub ruptura). Warto zwrócić uwagę, że demokratyzacja w postkomunistycznych krajach Europy Środkowo-Wschodniej dokonywała się na wszystkie trzy z powyższych sposobów.

\section{ROK 1989 - PRZEBIEG PROCESU DEMOKRATYZACJI W POLSCE}

Fazy polskiej rewolucji opisać można w sposób następujący: 1) głównego wyłomu w starym systemie dokonała „Solidarność” pomiędzy sierpniem 1980 a grudniem 1981 r.; 2) wprowadzenie stanu wojennego rozpoczęło okres kryzysu i wzmocnienia dychotomicznego podziału pomiędzy władzą i opozycja; 3) amnestia dla działaczy „Solidarności” we wrześniu 1986 r. rozpoczęła wstępne poszukiwanie kompromisu; 4) w decydujaccym okresie od rozpoczęcia obrad Okragłego Stołu do powstania rządu Tadeusza Mazowieckiego (6 lutego 24 sierpnia 1989 r.) z jednej strony nastapiło wynegocjowanie i osiagnięcie kompromisu pomiędzy częścią dotychczasowej władzy i częścią opozycji, z drugiej jednak - pojawiły się napięcia zarówno w obrębie władzy, jak i w łonie opozycji ${ }^{3}$.

Warto podkreślić stopniową zmianę celów demokratycznej opozycji. W okresie „pierwszej Solidarności” (1980-1981) polskie zmiany miały charakter „samoograniczajacej się rewolucji”, jako że „Solidarność” nie chciała (i nie mogła w ówczesnych warunkach) przejać władzy, chciała natomiast poprzez oddolny nacisk zmienić sposób jej sprawowania. W 1989 r. samoograniczenie zostało najpierw częściowo zniesione, ponieważ opozycja zdecydowała się na pewną formę współrządzenia, a potem - wobec rozmiarów zwycięstwa, szybkiej dekompozycji starego systemu władzy w Polsce, a także przemian i w ZSRR, i w krajach sasiednich - narastał nacisk na całkowite zniesienie tego samoograniczenia i pełną demokratyzację. Nastapiło to stopniowo w latach 1990 i 1991 przez przejęcie resortów siłowych w rządzie Tadeusza Mazowieckiego, a następnie - kolejne wolne wybory samorządowe, prezydenckie i parlamentarne.

Decydujacym momentem polskiego procesu demokratyzacji były obrady Okragłego Stołu, będące niejako uosobieniem „wspólnych działań rządu i ugrupowań opozycyjnych”. Jakakolwiek ocena Okragłego Stołu musi uwzględniać moment, w którym on się odbywał - pierwsze miesiące 1989 r., kiedy we wszystkich krajach obozu stacjonowały wojska radzieckie, a o zerwaniu żelaznej kurtyny można było co najwyżej marzyć. Wielu badaczy, zwłaszcza tych odwołujących się do teorii gier, ma tendencje do analizowania sytuacji w Pol-

3 J. Kubik, A. Linch, The Original Sin of Poland's Third Republic: Discounting "Solidarity" and its Consequences for Political Reconciliation, „Polish Sociological Review” 2006, nr 1 (153), s. $12-13$. 
sce w 1989 r. w postaci gry między czterema graczami: po stronie starego systemu grupa ortodoksyjna i grupa bardziej liberalna, po stronie opozycji grupa reformatorska i grupa radykalna. Tymczasem, mimo że rozmowy przy Okragłym Stole toczyły się formalnie między polskimi uczestnikami, to w istocie ciagle obecny był także gracz zewnętrzny, jako że władza na Kremlu nie pokazywała wówczas jasno, jak daleko pozwoli odejść Polsce od dotychczasowej komunistycznej ortodoksji. W tej sytuacji polscy gracze negocjowali między soba, ale ciagle wysyłali do Moskwy sygnały przedstawiajacce ich intencje, oczekując jednocześnie na sygnały pokazujące stanowisko władzy na Kremlu . Biorąc to pod uwagę, trzeba stwierdzić, że Okragły Stół był niewątpliwie sukcesem. Dokonując się w niezmiernie trudnych warunkach, Okragły Stół przyczynił się walnie do ich zmiany, a dzięki niemu wszystko, co dokonywało się potem, było już znacznie łatwiejsze.

Przebieg jego obrad, początkowe intencje obu stron i historia dochodzenia do konkretnych rozwiązań były wielokrotnie analizowane i dyskutowane. Nie wchodząc w tym miejscu w kwestie szczegółowe, podkreślić można, że chociaż najistotniejszym ustaleniem negocjacji było - jak twierdzą Hennie Kotzé i Pierre du Toit ${ }^{5}$ - doprowadzenie do częściowo wolnych wyborów, to wyjściowo nie chodziło o zdobycie większości w klasycznym parlamentarnym sensie, ale raczej o wynegocjowanie tego, by opozycja wzięła na siebie częściowa odpowiedzialność za kraj, zwłaszcza wobec zapaści gospodarczej. Tego chciała komunistyczna władza, godziła się też na to „Solidarność”, nie czując się wtedy w pełni przygotowana do całkowitego przejęcia władzy. Rzecz w tym jednak, że rozpoczęcie obrad uruchomiło proces, który nabrał własnej dynamiki, a żadna strona nie przewidziała tego, do czego doprowadzi ani sam Okragły Stół, ani tė̇ tego, co zaczęło się w Polsce po wyborach 4 czerwca 1989 r. Dziedzictwo Okragłego Stołu jest przedziwną mieszanką zrealizowanych zamierzeń i spełnionych obietnic, ale także i straconych złudzeń, a przede wszystkim niezamierzonych i niespodziewanych konsekwencji, przekraczajacych niejednokrotnie wyobraźnię jego uczestników, i to po obu stronach.

Przebieg wydarzeń w ciagu całego decydującego roku 1989 opisać można w znacznym stopniu w kategoriach dwóch typów napięć pomiędzy czterema wymienionymi wyżej „wewnętrznymi” graczami. Napięcie pierwsze dotyczyło relacji między głównymi stronami konfliktu i przeciwstawiało sobie logikę konfrontacji i logikę kompromisu pomiędzy władzą a „Solidarnością, w którym zwyciężyła - jak wiadomo - logika kompromisu. Napięcie drugie odnosiło się do relacji wewnątrz obu stron konfliktu i występowało pomiędzy logika wyłączenia, zgodnie z którą rozmawiały między sobą jedynie części elit obu stron wykluczające z negocjacji elementy bardziej radykalne, a logiką włączenia, zgodnie z która jakaśs rolę w podejmowaniu decyzji odgrywać chciały także inne grupy wewnątrz elit obu stron, a obie elity jako całości szukały wsparcia swojej „bazy”.

${ }^{4}$ Por. H. Kotzé, P. du Toit, Historical Context, w: U. van Beek (red.), Democracy under Construction: Patterns from Four Continents, Bloomfield Fields \& Opladen 2005, s. 283.

${ }^{5}$ Ibidem, s. 284.

${ }^{6}$ J. Kubik, A. Linch, op. cit., s. 15; por. też S. Huntington, op. cit., s. 129. 
To drugie napięcie nie znalazło ostatecznego rozwiązania. Część starego aparatu władzy ciagle dążyła do konfrontacji - traktowała ustalenia Plenum KC PZPR ze stycznia 1989 r. (które przyjęło logikę negocjacji) prawie jak zamach stanu, a potem formułowała zarzuty wyłączenia z rozmów. Owe podziały w łonie aparatu starego reżimu okazały się jednak - zwłaszcza na dłuższą metę - mniej istotne. Znacznie ważniejsze i dla późniejszej interpretacji rezultatów Okragłego Stołu, i szerzej - dla całej oceny III Rzeczypospolitej, były podziały wewnątrz opozycji.

Okragły Stół krytykowali najpierw ci przedstawiciele opozycji, którzy byli wykluczeni z rozmów, zarzucając bądź że negocjacje w ogóle nie miały sensu, bądź też, że chociaż Okragły Stół był potrzebny, to strona opozycyjna była po pierwsze nie w pełni reprezentatywna, a po drugie nie wykorzystała wszystkich możliwości (zwłaszcza nie „dociskając” odpowiednio strony przeciwnej po jej porażce wyborczej - dotyczyło to m.in. kompromisu po upadku listy krajowej oraz wyboru Wojciecha Jaruzelskiego na prezydenta ${ }^{7}$. Trzeba dodać, że pewna mniej zaangażowana politycznie część społeczeństwa traktowała ustalenia Okragłego Stołu jedynie jako odgórne negocjacje między elitami. Bezpośrednim skutkiem takiej postawy była dość duża, obejmująca $38 \%$ uprawnionych, absencja wyborcza 4 czerwca. Później postawa ta wpłynęła na polityczna i obywatelska apatię wielu grup Polaków. W pewnych środowiskach wreszcie krytyka Okragłego Stołu nasilała się z upływem czasu, wiążąc się z krytyką wielu aspektów zmian ekonomicznych, społecznych i kulturowych zachodzących w Polsce po 1989 r.

\section{DYLEMATY ZWYCIĘZCÓW: JAK SKONSOLIDOWAĆ DEMOKRACJĘ}

Zwycięstwo obozu „Solidarności” w 1989 r., oznaczające sukces samego procesu demokratyzacji, postawiło zwycięzców wobec szeregu wyzwań i decyzji, które wiązały się z kwestią już nie demokratycznego zdobycia władzy, ale „konsolidacji demokracji”, uczynienia z niej jedynego, nieodwracalnego instytucjonalnego systemu wyboru i sprawowania władzy. Pod względem czysto politycznym za kryterium konsolidacji demokracji uznać można test dwóch zmian ekip rządzących: ,jeżeli partia lub ugrupowanie, które zdobyło władzę w pierwszych wyborach czasu przemian, przegra następne wybory i odda władzę nowym zwycięzcom, a następnie ten rząd również odda władzę przy kolejnych wyborach"8. W Polsce w kolejnych wyborach parlamentarnych w latach 1991, 1993 i 1997 następowały radykalne zmiany ekip rządzących, co spełnia w całości to kryterium. Jak wiadomo, w późniejszych wyborach parlamentarnych z lat 2001 i 2005 następowała również całkowita wymiana ekip sprawujacych władzę, zmiany dokonywały się również w wyniku wyborów prezydenckich z lat 1990, 1995, a po kontynuacji w 2000 r. także z lat 2005 i 2010.

\footnotetext{
${ }^{7}$ Por. J. Kubik, A. Linch, op. cit., s. 16.

${ }^{8}$ S. Huntington, op. cit., s. 269.
} 
W Polsce mamy zatem już od lat dziewięćdziesiątych w pełni skonsolidowana demokrację polityczna.

Niezależnie jednak od sfery czysto politycznej każda nowa demokratyczna władza stoi wobec szeregu problemów i wyzwań. Te problemy i wyzwania mają charakter uniwersalny. Sposób i tempo ich rozwiązywania zależą jednak także od przebiegu wyjściowego procesu demokratyzacji, jak również i od specyficznych uwarunkowań lokalnych. Fakt, że dokonana w Polsce dzięki Okragłemu Stołowi zmiana systemu była wynikiem porozumienia elity dotychczasowej władzy z elitą demokratycznej opozycji wpłyną w pewnym stopniu na charakter i tempo dokonujących się w Polsce zmian, przyczyniając się zarówno do podejmowania szybkich decyzji w pewnych dziedzinach życia, jak i opóźnień i zaniechań w innych sferach.

Podstawowe problemy i wyzwania stojace przed nowa demokratyczna władzą w Polsce przedstawić chciałbym w odniesieniu do pracy Huntingtona. Przeprowadzając porównawczą analizę uniwersalnych problemów i wyzwań, wyprowadza on z tej analizy pewne wskazówki dla wprowadzających demokrację; wskazówki, które miałyby przyczynić się do długofalowego sukcesu demokracji, niezależnie od tego, że mogą one niekiedy sprawiać wrażenie nieco machiawelicznych. Huntington wymienia „problemy kontekstu”, „problem kata” oraz „problem pretorianina”.

Problemów kontekstu jest osiem ${ }^{9}$, spośród których trzy (duże wojny partyzanckie, konflikty etniczne oraz terroryzm) szczęśliwie nie dotyczą Polski. Pozostałe pięć ma charakter ekonomiczno-socjalny. Sam Huntington przypisuje Polsce dwa z nich (znaczne zadłużenie zagraniczne i znaczne zaangażowanie państwa w gospodarce). Trzy pozostałe to skrajne ubóstwo, ostre nierówności społeczno-ekonomiczne i chroniczna inflacja; w tym przypadku Polski na liście nie ma, ale choć sytuacja naszego kraju była pod tym względem lepsza niż w wielu innych demokratyzujacych się krajach, to wiadomo, że problemy ubóstwa i nierówności społecznych były i sa istotnym problemem w Polsce wpływającym także na ocenę wydarzeń $1989 \mathrm{r}$.

Lista Huntingtona uzupełniona być może czterema iluzjami opozycji demokratycznej. Zasiadająca przy Okragłym Stole elita opozycji, choć była historycznie częścia olbrzymiego społecznego ruchu „Solidarności” i posiadała przywódców robotniczych, składała się w większości z intelektualistów. Elita ta, podobnie jak członkowie opozycji demokratycznej w innych krajach bloku, walcząc przeciw komunistycznej dyktaturze, miała pewną wizję nowego, demokratycznego społeczeństwa opartego na pewnych ideałach, w istocie niemożliwych do spełnienia i będących w znacznej mierze iluzjami. Jacques Rupnik wymienia przynajmniej cztery takie iluzje: 1) kwestie ekonomiczne można wziać w nawias; 2) prymat etyki nad polityką - prawdziwa demokracja może opierać się na zasadach etycznych; 3) społeczeństwo obywatelskie może sprawować władzę; 4) intelektualiści mogą odgrywać dominującą rolę w życiu społecznym ${ }^{10}$. O ile pierwsza z owych iluzji wiąże się ściśle z Huntingtonowskimi

${ }^{9}$ S. Huntington, op. cit., s. 257.

${ }_{10}$ J. Rupnik, De l'antipolitique à la crise de la démocratie: que reste-t-il de l'héritage de la dissidence?, w: Ch. Lequesne, M. MacDonagh-Pajerova (red.), La citoyenneté démocratique dans l'Europe des vingt-sept, Paris 2007, s. 103-113. 
ekonomiczno-socjalnymi problemami kontekstu, to trzy pozostałe wiązały się z postulowanym idealnym kształtem demokracji i życia publicznego.

Wykorzystując obie te listy, chciałbym obecnie przyjrzeć się wyzwaniom pierwszych lat transformacji ekonomicznej, społecznej i politycznej w Polsce.

\section{GOSPODARCZE I SOCJALNE PROBLEMY TRANSFORMACJI: CHCIELIŚMY DEMOKRACJI, MAMY KAPITALIZM}

Od początku obrad Okragłego Stołu stało się oczywiste, że ekonomia wcale „nie da się wziać w nawias”. Tymczasem o ile polityczne ideały „Solidarności” były jasne, o tyle gospodarcze idee opozycji demokratycznej z początku lat osiemdziesiątych, wyrażane także w czasie obrad, były dość ogólne, miejscami naiwne i nie do końca spójne. Zmiany gospodarcze zaczęły się dopiero w 1990 r. wraz z wprowadzeniem reform Leszka Balcerowicza. Gospodarczy reformatorzy mieli przekonanie, że reprezentuja „interes teoretyczny”"11, czyli długofalowy interes całości społeczeństwa. Badania z kwietnia $1991 \mathrm{r} .{ }^{12}$ pokazały jednak wyraźnie, że politycy tzw. sejmu kontraktowego, i to wszystkich opcji, mieli ogólnie poglądy bardziej wolnorynkowe niż większość społeczeństwa. Posłowie reprezentowali ogólnie bardziej liberalną opcję ekonomiczna i za najważniejsze zadania uznawali „przyśpieszenie prywatyzacji”, „zwiększenie produkcji” czy „przyciagnięcie obcego kapitału”, podczas gdy społeczeństwo wykazywało orientację bardziej socjalna, a najistotniejsze dla niego były: „ograniczenie bezrobocia” czy „walka z inflacja”. W momencie rozpoczynania szokowej terapii gospodarczej konieczność dokonania zmian uznawali wszyscy, czy prawie wszyscy, ale przede wszystkim ze względu na zaufanie do nowej władzy, zdecydowane odrzucenie poprzedniego systemu i fascynację sukcesami rozwiniętych krajów kapitalistycznych. Jednakże szybko okazało się, że te niezbędne reformy ekonomiczne uderzały w krótkofalowe i partykularne interesy (a także mentalne przyzwyczajenia) wielu grup społecznych, przede wszystkim robotników wielkoprzemysłowych i rolników. Była to zresztą prawidłowość dotycząca całego regionu. Zmiana w Europie Środkowo-Wschodniej była dziwną rewolucja: ,,siły społeczne, które doprowadziły do upadku władzy komunistycznej, nie były tymi, które ostatecznie skorzystały z budowy nowego systemu"13. Polski paradoks polegał przy tym na tym, że reformy wprowadzające liberalną wersję kapitalizmu dokonywały się pod parasolem związku zawodowego i jego przywódcy Lecha Wałęsy. W efekcie Polacy, którzy

11 E. Mokrzycki, Dziedzictwo realnego socjalizmu, interesy grupowe i poszukiwanie nowej utopii „Kultura i Społeczeństwo” 35, 1991, nr 1.

${ }^{12}$ I. Białecki, W. Mach Orientacje społeczno-ekonomiczne posłów na tle pogladów społeczeństwa, w: J. Wasilewski, W. Wesołowski (red.), Poczatki parlamentarnej elity. Posłowie kontraktowego Sejmu, Warszawa 1992.

${ }_{13}$ Z. Bauman, After the Patronage State: A Model in Search of Class Interests, w: C. Bryan, E. Mokrzycki (red.), The New Great Transformation? Change and Continuity in East-Central Europe, London-New York 1994, s. 33. 
w latach osiemdziesiątych chcieli demokracji i poprawy sytuacji gospodarczej, po 1989 r. znaleźli się w kapitalizmie.

W Polsce pojawiło się dość szybko rozczarowanie rządami demokratycznymi i wynikami transformacji. To rozczarowanie (el desencanto) było jednak zjawiskiem powszechnym. Narastało ono, by przywołać Huntingtona ${ }^{14}$, „wkrótce po inauguracji demokratycznych rządów w Hiszpanii, Portugalii, Argentynie, Urugwaju, Brazylii, Peru, Turcji, Pakistanie, na Filipinach oraz w większości krajów Europy Wschodniej”. Wiązało się z rosnacym zrozumieniem, „że nadejście demokracji nie przyniesie, samo w sobie, rozwiązania podstawowych problemów gospodarczych i społecznych kraju. Niemożność rozwiązania problemów, ograniczenia stawiane przez proces demokratyczny, słabość przywódców politycznych - stawały się treścią codzienności”.

W Polsce stopniowo zmieniał się stosunek społeczeństwa do transformacji, co wyrażało się w wynikach wyborów parlamentarnych w 1991 i 1993 r. i wyborów prezydenckich w 1995 r. Jedynie mniejszość społeczeństwa głosowała ze względu na demokratyczne wartości, odrzucenie starego systemu i solidarnościowy rodowód, a coraz więcej osób zaczęło głosować ze względu na swoje interesy ekonomiczne i realne zagrożenia socjalne. Solidarnościowe elity popełniły niewątpliwie wiele taktyczno-politycznych błędów w latach 1990-1995. Wbrew jednak dominującej tendencji w naukach politycznych, traktujących rozwój demokracji głównie jako „rezultat strategicznych interakcji i układów między politycznymi elitami [...]”" , skłonny byłbym twierdzić, że ważniejszym jeszcze czynnikiem warunkujacym sytuacje polityczna w pierwszych latach przemian - zarówno w Polsce, jak i w innych krajach postkomunistycznych był podstawowy strukturalny problem (czy też dylemat) transformacji. Dylemat ten można sformułować następująco: Czy i jak system demokratyczny i jego instytucje zdolne są opanować, zinstytucjonalizować i częściowo przynajmniej rozwiązać podstawowy strukturalny konflikt pomiędzy krótkofalowymi partykularnymi interesami licznych grup społecznych a polityką ekonomiczna reformatorskich elit gospodarczych, wprowadzających, trochę z wyboru, ale bardziej z konieczności, kapitalizm jako „odgórny projekt demokratyczny” ${ }^{6}$.

W Polsce w pierwszej połowie lat dziewięćdziesiątych dylemat ten udało się częściowo rozwiązać, także przez zmiany ekip rządzących, co amortyzowało protesty społeczne. Udało się stosunkowo szybko przejść przez dolinę łez, czyli nieunikniony okres spadku produkcji i stopy życiowej, cięć socjalnych oraz wzrostu zróżnicowania społecznego i wejść na ścieżkę wzrostu gospodarczego, wytwarzając bazę społeczną nowego systemu (tzn. ludzi wiążących swoje interesy z nowym systemem), zanim nie wyczerpała się społeczna cierpliwość dużej, odczuwającej ciężar wyrzeczeń części społeczeństwa i nie zdobyli przewagi przeciwnicy reform.

14 S. Huntington, op. cit., s. 258-259.

15 D. C. Shin, On the Third Wave of Democratization: A Synthesis and Evaluation of Recent Theory and Research, „World Politics” 47, 1994, October, s. 139.

${ }^{16}$ Por. C. Offe, Capitalism by Democratic Design: Democratic Theory Facing the Triple Transition in East Central Europe, „Social Research” 58, 1991, nr 4; M. Ziółkowski, Structural Dilemma of the Transformation and the Functioning of the Political System, „Current Politics and Economics of Europe" 7, 1998, nr 4. 


\section{NIEPEŁNE ROZLICZENIE PRZESZŁOŚCI: „PROBLEM KATA”}

Kolejnym podstawowym problemem transformacji była kwestia rozliczania przeszłości. Jest to - jak go nazywa Huntington - ,problem kata”, odnoszący się do tego, ,jak należy traktować funkcjonariuszy reżimu autorytarnego, którzy jawnie łamali prawa człowieka"17. Polskie dylematy w tej kwestii nie były bynajmniej wyjątkowe. W wielu krajach, zwłaszcza tych, w których nie trzeba było zmieniać fundamentów systemu gospodarczego, sposób rozliczania zbrodni autorytarnych rządów był w istocie głównym problemem okresu demokratyzacji. Dotyczyło to np. Grecji, Argentyny, Chile, Filipin, a w szerszym, międzyrasowym kontekście - Republiki Południowej Afryki. W fundamentalnym sporze „sądzić i karać czy przebaczyć i zapomnieć” przytacza się szereg argumentów o charakterze prawnym, moralnym, a także pragmatycznym ${ }^{18}$.

Sposób rozwiązywania tego problemu w Polsce wyznaczyły zarówno umowa zawarta przy Okragłym Stole, jak i późniejsze zawirowania na scenie politycznej. Generalnie można stwierdzić, że polityka traktowania zbrodniarzy i kolaborantów, ale także i ofiar komunistycznego reżimu była w Polsce zmienna i niekonsekwentna - stanowiła mieszankę poszukiwania prawdy, wymierzania sprawiedliwości, wyrównywania krzywd, pojednania i przebaczenia, politycznego pragmatyzmu oraz politycznych rozgrywek i manipulacji.

Oczywiste jest, że rozliczenie przeszłości nie było możliwe ani przy Okragłym Stole, ani w pierwszych miesiącach funkcjonowania pierwszego solidarnościowego rządu. Wydaje się jednak, że nie wykorzystano kolejnych pojawiających się okazji, albo przez błąd zaniechania (np. po „wyprowadzeniu sztandaru” i rozwiązaniu PZPR w styczniu 1990 r.), albo przez radykalne próby lustracji nierozliczające rzeczywistych sprawców, a wykorzystujące listy tajnych agentów do walki politycznej w obrębie ruchu solidarnościowego (czerwiec 1992 r.). Z powodu podziałów w dawnej opozycji funkcjonariusze poprzedniego systemu bardzo szybko, gdyż już w 1993 r., powrócili do władzy, a przez cały czas okupowali wiele urzędów średniego szczebla, co pozwoliło im na rozmycie bądź zablokowanie bardziej zdecydowanych działań rozliczeniowych. Widać to było zwłaszcza w funkcjonowaniu polskiego wymiaru sprawiedliwości, znanego z przewlekłości i nieskuteczności jego procedur i niepotrafiącego osądzić i ukarać nawet najbardziej oczywistych zbrodni komunistycznych. Tymczasem jednym z podstawowych wniosków analizy porównawczej jest to, że „w nowych systemach demokratycznych sprawiedliwość przychodzi szybko, lub nie przychodzi wcale"19. Należy się też zgodzić z kolejną uwagą Huntingtona, że „głównym czynnikiem ograniczającym ściganie karne i ujawnianie prawdy w byłych krajach komunistycznych było przesycenie reżimem całego społeczeństwa; stopień, do jakiego wielu ludzi akceptowało go i kolaborowało z nim; oraz obawa przed tym, co takie procesy czy badania mogłyby wykazać" ${ }^{20}$.

17 S. Huntington, op. cit., s. 214.

18 Ibidem, s. 218-220.

19 Ibidem, s. 233.

20 Ibidem, s. 235. 
W efekcie społeczeństwo polskie nie doczekało się ani rzeczywistego ukarania zbrodniarzy, ani dekomunizacji, ani autentycznej lustracji, ani - jako jedyne w całym bloku - restytucji własności (reprywatyzacji). W tej sytuacji stosunek do przeszłości stał się drugim (obok kwestii ekonomiczno-socjalnych) istotnym elementem politycznej rywalizacji: jedni wykorzystywali postkomunistyczną nostalgię do zdobycia wyborczego poparcia, innym wystarczała krytyka przeszłości, a w szczególności komunistycznej wizji historii, dla innych wreszcie pamięć o komunistycznych zbrodniach i wyrównywanie krzywd i niesprawiedliwości stało się główną racją istnienia.

Uznając wszystkie nieprawidłowości polskiego sposobu rozliczania przeszłości, uznać trzeba także końcowy, wynikający z analizy porównawczej, wniosek Huntingtona: „przy wyborze "oskarżać i karać czy przebaczać i zapominać« każda decyzja oznacza pojawienie się groźnych problemów, a najmniej niezadowalającym rozwiązaniem być może będzie: nie oskarżać, nie karać, nie wybaczać i - przede wszystkim - nie zapominać" ${ }^{21}$. Wydaje się, że w dzisiejszej Polsce - w sposób mniej lub bardziej chciany czy zamierzony - stopniowo osiagnięto wspólnie efekt zbliżony do tego „najmniej niezadowalającego rozwiązania”.

Uwzględnić należy także inną okoliczność. Pamięć o przeszłych przywilejach, krzywdach i niesprawiedliwościach jest istotna wtedy, gdy żyja jeszcze bezpośredni beneficjenci przywilejów oraz sprawcy i ofiary krzywd i niesprawiedliwości, ale i wtedy, gdy odpowiedzialność może być w pewien sposób dziedziczona, przenoszona na następne pokolenia i całą grupę czy wspólnotę. Jeżeli istnieje poczucie dziedziczenia, zawsze można rozumować w sposób następujący: „Oni nas pozbawili majątku, oni nas prześladowali”, niezależnie od tego, czy przywoływane zdarzenia miały miejsce dwadzieścia czy dwieście lat temu. Rzecz w tym, że owo poczucie dziedziczenia jest stopniowalne; występuje najsilniej w konfliktach rasowych (,biali znęcali się nad czarnymi”), nieco słabiej w konfliktach etnicznych czy religijnych (między Polakami a Ukraińcami, czy protestantami a katolikami), a stosunkowo najsłabiej w konfliktach politycznych w kulturowo i etnicznie jednolitych społeczeństwach. W Polsce nie udało się ani rozliczyć bezpośrednich beneficjentów, ani ukarać bezpośrednich sprawców krzywd, ale przeciwstawienie „my-oni” z poprzedniego systemu zaniknie (w przeciwieństwie np. do RPA) w ciagu jednego, najwyżej dwóch pokoleń. Tak jak nie dziedziczyło się różnic pomiędzy zwolennikami Piłsudskiego i Dmowskiego, tak o ile dzieciom poprzednich aparatczyków można ewentualnie zarzucać, że korzystają z „uwłaszczenia nomenklatury” (czyli - inaczej mówiąc - konwersji pewnej specyficznej formy kapitału społecznego ${ }^{22} \mathrm{w}$ kapitał materialny), o tyle ich wnuki nie będą się różnić od resz-

21 Ibidem, s. 236.

22 E. Wnuk-Lipiński nazywa tę formę kapitału społecznego „kapitałem politycznym”, definiując go jako „taki zasób indywidualnych cech człowieka nabytych w wyniku wcześniejszego zaangażowania w politykę, dzięki któremu jest on premiowany przetrwaniem w elicie władzy lub selekcją na wyższe pozycje w strukturze władzy [...]" (idem, Demokratyczna rekonstrukcja, Warszawa 1996, s. 149). 
ty społeczeństwa (mimo pojawiających się ostatnio prób stygmatyzowania np. „resortowych dzieci”).

Dwie sa konsekwencje tego stanu rzeczy. Pierwsza, że problem rozliczania przeszłości rozwiązuje się sam wraz z upływem czasu: nie będzie już kogo karać, ani komu wybaczać, a chodzi o to, by nie zapominać. Druga, znacznie bardziej optymistyczna, że uczestnicy obu stron konfliktu, a tym bardziej ich potomkowie, dlatego właśnie, iż był to głównie konflikt polityczny w obrębie tej samej wspólnoty, moga wspólnie uczestniczyć w budowie demokratycznej Polski i wspólnie korzystać z jej osiagnięć.

\section{VII. „PROBLEM PRETORIANINA”}

Kolejna kwestia - „problem pretorianina” - dotyczy tego, jak zmniejszyć udział wojska, a także policji w polityce i ustanowić profesjonalny układ stosunków pomiędzy sferą cywilną a wojskiem, zwłaszcza przez poddanie wojska, policji i służb specjalnych demokratycznej kontroli cywilnej. Kwestia ta miała fundamentalne wręcz znaczenie w wielu demokratyzujących się krajach południa Europy czy Ameryki Łacińskiej. W krajach komunistycznych wojsko zwykle nie stanowiło samodzielnej siły politycznej, było bądź podporządkowane partii, bądź się z nią przenikało, choć niekiedy - jak np. w Polsce przy powołaniu WRON-u i wprowadzeniu stanu wojennego - nabierało specjalnego znaczenia.

Uzyskanie poparcia albo przynajmniej neutralności „resortów siłowych” w procesie ustanawiania demokracji, a potem ich przebudowa w nowym systemie, choć było w Polsce mniejszym problemem niż np. w Hiszpanii, Argentynie czy Chile, stanowiły także trudne zadanie. Huntington daje tu znowu wynikające z analizy porównawczej wskazówki ${ }^{23}$. W Polsce, co wynikało ze sposobu przejęcia władzy i początkowego składu pierwszego rządu solidarnościowego, nie udało się jednak zrealizować podstawowej pierwszej wskazówki z listy: „Należy szybko zwolnić lub przenieść na emeryturę wszystkich potencjalnie nielojalnych oficerów, w tym czołowych zwolenników reżimu autorytarnego [...]”24. Inne konsekwencje ówczesnej sytuacji to jedynie stopniowe i opóźnione przejęcie kontroli przez stronę solidarnościową nad resortami siłowymi, dopuszczenie do palenia akt w archiwach, a także częściowa i wzbudzająca różne wątpliwości weryfikacja funkcjonariuszy milicji, Służby Bezpieczeństwa i Wojskowych Służb Wewnętrznych. Wyzwaniem było także tworzenie nowych służb, w których zatrudniano zarówno starych funkcjonariuszy, jak i nowych kandydatów, a przedmiotem kontrowersji stały się zwłaszcza nowo utworzone Wojskowe Służby Informacyjne. Teza o znacznej roli przedstawicieli starych służb w nowej rzeczywistości była jednym z podstawowych argumentów krytyków rezultatów Okragłego Stołu i funkcjonowania III Rzeczypospolitej. Podkreślali oni najczęściej korzyści indywidualne wspierających się wzajem-

\footnotetext{
${ }^{23}$ S. Huntington, op. cit., s. 255-256.

${ }^{24}$ Ibidem, s. 255.
} 
nie przedstawicieli starych służb, co miało niekiedy miejsce, będąc elementem wspomnianego wyżej szerszego procesu „uwłaszczenia nomenklatury”. Krytycy ci niekiedy szli znacznie dalej, sugerując - zwykle poprzez nieweryfikowalne insynuacje medialne - możliwą nielojalność niektórych przedstawicieli tych służb wobec Państwa Polskiego i działanie na rzecz mocodawców zewnętrznych.

Generalnie jednak przejęcie pełnej demokratycznej kontroli nad wojskiem i policją przebiegało sprawnie i zakończyło się sukcesem. Polskie władze cywilne wykorzystywały przy tym wiele różnych sposobów do zdobycia lojalności służb mundurowych, a zwłaszcza armii, postępując jak gdyby w myśl kolejnych wskazówek Huntingtona, które brzmią bardzo pragmatycznie, niekiedy nieco cynicznie, a czasem wręcz zabawnie. Oto niektóre z nich: „[...] wykorzystać pieniądze zaoszczędzone $\mathrm{w}$ związku z ograniczeniem liczebności wojska na zwiększenie płac, emerytur i świadczeń socjalnych oraz poprawę warunków mieszkalnych. Opłaci się"; „[...] wojsku należy dostarczać zabawek [...] wyposażać [...] w nowe modele czołgów, samolotów”; „[...] ponieważ żołnierze [...] lubią być lubiani, należy korzystać z każdej okazji, by identyfikować się z własnym wojskiem. Konieczne będzie uczestniczenie w ceremoniach wojskowych; rozdawanie medali [...]"25. Wydaje się, że polska demokratyczna władza dość skutecznie prowadziła i nadal prowadzi taką właśnie politykę.

\section{DOŚWIADCZENIA ROKU 1989 A FUNKCJONOWANIE POLSKIEJ DEMOKRACJI I DEBATY PUBLICZNEJ}

Kolejnym pytaniem jest to, czy i w jakim stopniu przebieg i kształt polskiej zmiany systemowej w roku 1989 miały wpływ na dalsze funkcjonowanie polskiej demokracji i debaty publicznej. Odpowiedź na to pytanie wcale nie jest prosta. Wydaje się, że pod tym względem zdecydowanie dominujace pozytywne doświadczenia roku 1989 stopniowo traciły swoje znaczenie.

Okragły Stół był debatą dwóch elit, traktujących się początkowo z olbrzymią nieufnością i dopiero stopniowo uczących się słuchać i rozumieć racje drugiej strony. Jak podkreśla np. Michael Kennedy ${ }^{26}$, Okrągły Stół dostarczył Polsce pewnego wzorca postępowania, stanowiąc o sile polskiej demokracji i braku przemocy. Jego obrady, niezależnie od wyjściowych intencji, były znakomitą szkoła dialogu prowadzącego do porozumienia. Autentyczna debata polityczna toczyła się także i w sejmie kontraktowym, którego członkowie mieli poczucie wspólnego budowania czegoś nowego, realizacji dobra wspólnego i ,interesu teoretycznego”. Stopniowo jednak rola autentycznego dialogu w polskim systemie politycznym zaczęła spadać. Decyzje polityczne podejmuje się przede wszystkim w zaciszu gabinetów (ministerstw, w gronie doradców).

25 Ibidem, s. 256.

${ }_{26}$ M. Kennedy, Cultural Formations of Postcommunism: Emancipation, Transition, Nation and War, Minneapolis 2002. 
Debata i wymiana argumentów pojawiają się w głównie w czasie społecznych konsultacji, obrad komisji trójstronnej, niekiedy na posiedzeniach komisji parlamentarnych. Przemówienia na posiedzeniach plenarnych są natomiast głównie - niekiedy bardzo sprawnymi retorycznie - popisami medialnymi, przy których z góry wiadomo, kto co powie.

Słabość debaty publicznej ma dwie główne przyczyny. Przyczyną pierwsza jest medializacja polityki. Debata publiczna toczy się głównie w mediach, a zwłaszcza $\mathrm{w}$ telewizyjnych potyczkach gadających głów w trakcie wielogodzinnych programów informacyjno-dyskusyjnych. Prowadzący dyskusje dziennikarze wręcz napuszczają na siebie dyskutantów, chodzi im o wywołanie ostrej dyskusji, konfliktu, sporu, doprowadzenie do wymiany mniej lub bardziej błyskotliwych i mniej lub bardziej eleganckich bons mots, czy nawet inwektyw. Nie ma tam ani czasu, ani miejsca na autentyczną dyskusję i wymianę rzeczowych argumentów. Rzeczywisty dialog publiczny ma miejsce jedynie w niektórych ambitniejszych tytułach prasowych.

Przyczyną drugą jest nasilająca się ideologizacja polskiej polityki. Coraz mniej spraw traktowanych jest jako konflikt realistyczny ${ }^{27}$, w którym chodzi o rozwiązanie konkretnego problemu, a coraz więcej staje się konfliktami nierealistycznymi, przy których wyraża się głównie „zgeneralizowaną wrogość” do drugiej strony. Problemy ekonomiczne, np. „pomostówki” czy pomoc dla stoczni, są traktowane jako ideologiczne, a kanon lektur szkolnych czy handel gazem z Rosją rozpatrywane są niemal w kategoriach zdrady narodowej. Prowadzi to do dalszej polaryzacji sceny politycznej i bardzo utrudnia poszukiwanie rozwiązań kompromisowych.

Warto zwrócić uwagę na jeszcze jedną złudną obietnicę roku 1989. Powstanie „Solidarności” w 1980 r. i jej zwycięstwo w 1989 były wynikiem współpracy dwóch zwłaszcza grup społecznych: wielkoprzemysłowych robotników i opozycyjnej inteligencji. W obradach Okragłego Stołu i późniejszej działalności Obywatelskiego Klubu Parlamentarnego i pierwszego solidarnościowego rządu olbrzymią rolę odgrywała inteligencja. Jej przedstawiciele - twórcy, artyści, uczeni - ponieważ jako jedyni spełniali dwa istotne kryteria: byli znani z okresu PRL, ale i względnie niezależni od starego systemu władzy, stali się naturalnymi kandydatami „Solidarności” w całkowicie demokratycznych wyborach do Senatu i zdominowali jego pierwszy skład.

Niektórym przedstawicielom inteligencji wydawało się wówczas, że sa prawowitymi reprezentantami polskiego społeczeństwa jako całości, przedstawicielami kategorii „my”, naprzeciw której stali „oni”, czyli władza. Tego odczucia inteligencji, że rozumie i reprezentuje odczucia i dążności większości Polaków, inne środowiska bynajmniej jednak nie podzielały. W zrealizowanych z Jadwiga Koralewicz w grudniu 1988 r. badaniach prosiliśmy respondentów o zaliczanie poszczególnych osób i grup społecznych do jednej z trzech kategorii: „my”, „oni” i „reszta”. Schematyczne wyniki były następujące:

${ }^{27}$ Por. L. A. Coser, Społeczne funkcje konfliktu, w: A. Jasińska-Kania et al. (red.), Wspótczesne teorie socjologiczne, Warszawa 2006, s. 481. 


\begin{tabular}{|l|l|l|l|}
\cline { 2 - 4 } \multicolumn{1}{c|}{ O inteligencji } & \multicolumn{1}{c|}{ O robotnikach } & \multicolumn{1}{c|}{ O chłopach } \\
\hline Inteligencja & my & my & my \\
\hline Robotnicy & reszta & my & my \\
\hline Chłopi & reszta & reszta & my \\
\hline
\end{tabular}

Wyniki pokazują wyraźna „,asymetrię postrzegania wspólnoty”, o ile inteligenci mieli poczucie przynależności do wspólnoty ogólnonarodowej, to robotnicy do kategorii „my” zaliczali obok siebie tylko chłopów, a chłopi jedynie samych siebie. Przedstawione wyżej ustalenia badań zdają się dobrze tłumaczyć m.in. wyniki wyborów prezydenckich w 1990 r., a zwłaszcza fakt, że Tadeusz Mazowiecki nie wszedł do drugiej tury.

\section{ROK 1989 W PAMIĘCI POLAKÓW - SPOLECZNA OCENA PO LATACH}

Przedstawić chciałbym obecnie pewne elementy tego, jak dokonana w roku 1989 zmiana systemowa jest społecznie oceniana po ponad dwudziestu la$\operatorname{tach}^{28}$. Na podstawowe pytanie: „Czy warto było w 1989 roku zmieniać ustrój?” w kolejnych badaniach zdecydowana większość Polaków odpowiadała „tak”, w 2010 r. odpowiedź tę wybrało 83\% respondentów. To, że zmiany w Polsce przyniosły więcej korzyści niż strat, uważa 47\%, pogląd przeciwny uznaje $16 \%$, a $30 \%$ twierdzi, że przyniosły one tyle samo korzyści i strat. Ta pozytywna ocena przemian formułowana jest mimo tego, że przy pytaniu o sytuację swoją i swojej rodziny dominująca odpowiedzią jest, że respondenci ani nie zyskali, ani nie stracili na zmianach (49\%), jedynie $24 \%$ twierdzi, że zyskało, a $16 \%$ - że straciło.

Za najbardziej przełomowe wydarzenie, które doprowadziło do upadku komunizmu w Polsce, uznawany jest Okragły Stół, wymieniany przez 40\% respondentów (badania z 2008 r.). W 2014 r. ocenia go pozytywnie $42 \%$ respondentów, jedynie $10 \%$ negatywnie, a $37 \%$ twierdzi, że ma do niego stosunek obojętny i że go to nie interesuje. Warto dodać, że ta ostatnia grupa stopniowo rośnie (w 2009 r. było to tylko 31\%), a brak zainteresowania - co zresztą naturalne - deklaruje najliczniej: aż w 45\% najmłodsze pokolenie (18-24 lata).

W badaniach ze stycznia $2014 \mathrm{r}$. odpowiadających proszono o wybranie określenia, które lepiej pasuje do porozumienia zawartego przy Okragłym Stole. Rozkład odpowiedzi przedstawia się następująco: „Demokratyczna rewolucja - to nacisk społeczny spowodował upadek totalitarnego reżimu" 17\%; „Porozumienie elit - przedstawiciele władzy i »Solidarności« znaleźli korzystny dla wszystkich kompromis” - 37\%; „Zmowa elit - przedstawiciele

${ }^{28}$ Wykorzystuję tu wyniki badań CBOS-u: z 2008 r., ze stycznia 2009 r., badanie „»Solidarność - doświadczenie i pamięć” zrealizowane wspólnie przez CBOS i Europejskie Centrum Solidarności w 2010 r. i przedstawione w komunikatach CBOS-u: 94/2010 i 101/2010, oraz badanie ze stycznia 2014 r. - 16/2014. 
władzy i »Solidarności« znaleźli kompromis, który miał być korzystny przede wszystkim dla nich samych” - 15\%; „Manipulacja służb specjalnych - całość przemian odbyła się pod kontrolą agentury umieszczonej w kluczowych instytucjach i środowiskach” - 6\%; „Trudno powiedzieć” - 25\%.

Za „najbardziej właściwy w ówczesnej sytuacji” sposób przeprowadzenie zmian politycznych uznaje go dzisiaj $27 \%$ ankietowanych, a $41 \%$ zgadza się z twierdzeniem, że „miał dobre strony, ale kompromis był za daleko posunięty”, gdy jedynie $11 \%$ ocenia go jako „niepotrzebne ustępstwo wobec władz komunistycznych". Pogląd, że był to sposób najwłaściwszy, jest tym częstszy, im wyższe jest wykształcenie badanych. Charakterystyczne jest natomiast to, że w grupach najmłodszych wyraźnie przeważa krytycyzm wobec porozumienia Okragłego Stołu.

Ocena wydarzeń 1989 r. nieco się zmienia z upływem lat. Wskazuje na to porównanie wyników z 2009 i 2014 r. Olbrzymia większość Polaków uważa niezmiennie, że porozumienie Okragłego Stołu „umożliwiło pokojowe bezkrwawe przekazanie władzy (2009: tak - 74\%, nie - 8\%; 2014: tak - 75\%, nie 10\%). Rośnie jednak jednocześnie akceptacja twierdzenia, że porozumienie to „spowodowało, że w Polsce nie doszło do rozliczenia systemu i jego głównych przedstawicieli" (2009: tak - 51\%, nie - 21\%; 2014: tak - 57\%, nie - 18\%). Ciagle mniejszość osób sądzi, że „porozumienie było niepotrzebne, bo i tak stary system wkrótce by upadł", ale ta mniejszość rośnie (2009: tak - 27\%, nie - 47\%; 2014: tak - 34\%, nie - 43\%). Tak więc Okragły Stół oceniany jest z perspektywy lat generalnie pozytywnie przez większość społeczeństwa, ale w miarę upływu czasu (i zwłaszcza w młodszym pokoleniu) zanika pamięć o ówczesnych uwarunkowaniach, np. geopolitycznych, a zdaje się narastać przekonanie, że upadek systemu był przesądzony i można było działać bardziej zdecydowanie.

Większość Polaków pozytywnie ocenia jednak także dalsze postępowanie strony solidarnościowej w 1989 r. Na pytanie w 2010 r., co należało przede wszystkim zrobić po wyborach do Sejmu i Senatu i utworzeniu rządu Tadeusza Mazowieckiego, 54\% wybrało odpowiedź, że „dążyć do porozumienia ponad podziałami i włączyć wszystkie grupy społeczne i siły polityczne w budowę demokracji”, a jedynie - $29 \%$ odpowiedź, że „dążyć do rozliczenia starego systemu i jego funkcjonariuszy”. Warto jednak podkreślić, że częściej niż przeciętnie tę drugą odpowiedź wybierali dawni członkowie „Solidarności” (którzy są mniej zadowoleni ze sposobu wykorzystania swojego zwycięstwa), a zdecydowanie rzadziej byli członkowie PZPR.

Charakterystyczne sa odpowiedzi na powtarzane dwukrotnie w 2008 i 2010 r. pytanie: „Jakie błędy i zaniechania popełniono w okresie przemian po 1989 roku?". Z listy, z której każdy respondent mógł wybrać nie więcej niż trzy błędy, hierarchia odpowiedzi w 2008 i w 2010 r. była identyczna, w 2010 najczęściej wymieniano: „tolerowanie korupcji, nieuczciwości w polityce” (37\%); ,zbyt daleko idąca prywatyzacja polskiej gospodarki, wyprzedaż majątku narodowego za bezcen” (29\%) oraz „dopuszczenie do nadmiernego wzrostu nierówności społecznych" (27\%). Na dalszych trzech miejscach wymieniane sa: „brak wystarczającej lustracji, rozliczenia współpracowników służb specjal- 
nych PRL” (24\%); „,brak dekomunizacji i rozliczenia funkcjonariuszy państwowych i partyjnych z okresu PRL” (24\%) oraz „uwłaszczenie nomenklatury, przejmowanie państwowego majątku przez działaczy partyjnych i państwowych" (22\%).

Hierarchia odpowiedzi wskazuje, że przy ogólnej dominującej ocenie, że warto było zmieniać system, elementy oceny krytycznej dotycza, obok „ponadsystemowej" korupcji, najczęściej niektórych skutków realizowanych systemowych reform gospodarczych, a rzadziej - błędów w traktowaniu i rozliczaniu funkcjonariuszy starego systemu. Krytyka dotyczy zatem bardziej natury polskiego kapitalizmu jako systemu gospodarczo-społecznego niż negatywnych konsekwencji samego procesu wprowadzania w Polsce w 1989 r. demokratycznych zmian w efekcie „wspólnych działań rządu i ugrupowań opozycyjnych”.

Społeczną ocenę wydarzeń roku 1989 i ocenę całego ostatniego ćwierćwiecza można więc podsumować w sposób następujący: 1) są one silnie wzajemnie skorelowane; 2) sa zróżnicowane i zależą od tego, czy ocen tych dokonuja „wygrani” czy „przegrani” polskich przemian, co uwidacznia się najwyraźniej przy rozbiciu ocen na poszczególne kategorie respondentów; 3) oceny pozytywne w obu przypadkach przeważają nad negatywnymi; 4) krytyka przebiegu wydarzeń 1989 r. jest formułowana rzadziej i mniej ostro niż krytyka niektórych cieni dwudziestu pięciu lat funkcjonowania polskiej transformacji. Obraz „chwalebnej przeszłości”, czyli zwycięskiej polskiej pokojowej rewolucji sprzed 25 lat, jest zatem jaśniejszy niż obraz współczesności będącej tej rewolucji konsekwencja. Wydarzenia 1989 r. - mimo wszelkich wątpliwości - sa postrzegane przede wszystkim jako wspólny narodowy sukces, wpływający na los całego regionu; przy ocenie współczesności natomiast silniej uwzględnia się jej wady, traktując je jako winę rozwiązań systemowych, podczas gdy jej sukcesy i osiagnięcia przypisuje się częściej własnej indywidualnej aktywności bądź uznaje za rzecz naturalną.

\section{ZAKOŃCZENIE - JAK KULTYWOWAĆ PAMIĘĆ O WYDARZENIACH ROKU 1989 I CO UZNAĆ ZA SYMBOLICZNY POCZĄTEK III RZECZYPOSPOLITEJ?}

Uwzględniając przemiany ostatnich 25 lat, a także społeczne oceny tych przemian, chciałbym wyrazić swoje głębokie przekonanie, że niezależnie od wszystkich problemów ostatnie ćwierćwiecze w historii Polski jest olbrzymim sukcesem. Sukces ten widoczny jest zwłaszcza na tle porównawczym. Najważniejszymi pozagospodarczymi osiąnięciami tego ćwierćwiecza sa: odzyskanie pełnej niepodległości, radykalna zmiana sytuacji geopolitycznej i zewnętrznego bezpieczeństwa kraju (także dzięki wejściu do NATO), wprowadzenie i konsolidacja systemu demokratycznego, uzyskanie pełni swobód politycznych i obywatelskich oraz otwarcie granic. Sukcesem jest także rozwój samorządności, rozpoczęty przygotowywaną już od 1989 r. wielką reformą samorządowa, oddającą wspólnotom lokalnym decydowanie o ich małych ojczyznach. 
To ćwierćwiecze jest również niewątpliwym sukcesem gospodarczym. Dochód narodowy na głowę mieszkańca Polski (liczony według parytetu siły nabywczej pieniądza) w stosunku do średniej dla obecnych 28 członków Unii Europejskiej wzrósł z 42\% w 1990, 48\% w 2001, do 67\% w 2012 r. ${ }^{29}$ Podjęte wbrew odczuciom większości społeczeństwa decyzje wprowadzajace liberalny system rynkowy w gospodarce okazały się już po kilku latach - mimo wszystkich swoich niepożądanych efektów ubocznych - korzystne dla całego społeczeństwa. Nie chodzi tylko o poprawiający się szybko średni poziom życia, chodzi też o zaopatrzenie, wyposażenie gospodarstw domowych, ułatwienia w życiu codziennym i rozwój infrastruktury. Jednym z istotnych czynników wzrostu gospodarczego kraju było przystapienie Polski do Unii Europejskiej w 2004 r., które nie byłoby oczywiście możliwe bez wcześniejszej zmiany systemu.

Czynnikiem negatywnym był natomiast wzrost społecznych nierówności, a silną społeczną reakcję wywołuje zwłaszcza akcentowany wyżej fakt, że statystycznie ci, którym żyło się lepiej w starym systemie (a więc także i jego funkcjonariusze), również obecnie reprezentują wyższy poziom życia. Jednakże poziom społecznych nierówności w Polsce, choć początkowo rósł, to zaczął następnie spadać szczególnie dzięki subwencjom europejskim dla rolników i sytuuje się obecnie w pobliżu średniej europejskiej ${ }^{30}$. Nawet najuboższej jednej czwartej ludności kraju żyje się obecnie zdecydowanie lepiej niż 25 lat temu. Społeczeństwo polskie jako całość zaakceptowało i demokrację (której budowę zaczęto w roku 1989) i kapitalistyczny system rynkowy (o którym na początku nikt prawie jeszcze nie myślał).

Przełom w najnowszej historii Polski nastapił właśnie 25 lat temu, w roku 1989. Był to jednak przełom pokojowy, przeprowadzony bez użycia przemocy, a więc niewymagający aktów osobistego poświęcenia i niemający swoich poległych bohaterów, ale niedający również poczucia należytego i zdecydowanego rozliczenia i ukarania tych, którzy na to zasłużyli. Był to też przełom rozciagnięty w czasie, dokonujacy się poprzez kolejne stadia, zawierajacy obok elementów radykalnego zerwania także elementy kontynuacji. Pamięć o naturze starego systemu, o dokonaniach roku 1989 oraz o ich ówczesnych, zwłaszcza geopolitycznych uwarunkowaniach stopniowo się zaciera, nawet wśród starszego pokolenia, które doświadczyło i życia w starym systemie, i solidarnościowej rewolucji. Pamięć ta, jak wykazują choćby przytaczane wyżej wyniki badań, nie jest też ze zbyt dobrym efektem przekazywana najmłodszemu pokoleniu.

Wydaje się, że we współczesnej Polsce brak pamięci, dumy i docenienia wszystkich osiagnięć ostatniego ćwierćwiecza. Wynika to z różnych przyczyn, ale jedna z nich jest brak symbolicznego zamknięcia starego systemu i rozpoczęcia nowego. Świętujemy raczej wydarzenia odleglejsze (3 maja 1791,

29 Eurostat, dane z 15 listopada 2013 r.

${ }^{30}$ Wskaźnik Giniego z uwzględnieniem podatków i świadczeń społecznych (gdzie 0 oznacza brak nierówności, a 1 ich maksimum) wynosił na początku transformacji ok. 0,28, potem wzrósł do 0,35 w 2005 r., by następnie spadać, osiagając 0,305 w 2011 r. Wskaźnik dla Polski zbliża się obecnie do średniej europejskiej i jest nieco wyższy niż w Niemczech i Francji, ale niższy niż we Włoszech i Wielkiej Brytanii, nie mówiąc już o Rosji, USA czy niektórych krajach Ameryki Łacińskiej (dane OECD). 
11 listopada 1918 czy nawet 1 sierpnia 1944), nie ma natomiast zgody ani co do dat, ani co do oceny wydarzeń, które leżą u początków III Rzeczypospolitej, są jej „aktem założycielskim”. Jan Kubik i Amy Linch ${ }^{31}$ określają to brakiem „pojednania pamięci” (mnemonic reconciliation), który to brak uniemożliwia wytworzenie wspólnej tradycji i wspólnego świętowania dat, wydarzeń i ich bohaterów.

Takie pojednanie pamięci wydaje się w Polsce bardzo potrzebne. Jego elementem byłoby też przyjęcie jednej wspólnej symbolicznej daty wyznaczającej początek III Rzeczypospolitej. W'śód wydarzeń roku 1989 najistotniejsze były obrady Okragłego Stołu, wybory 4 czerwca i utworzenie pierwszego rządu solidarnościowego. W mojej i nie tylko mojej opinii największym przełomem były wybory 4 czerwca 1989 r., ów dzień, w którym „skończył się w Polsce komunizm”. Dlatego też, zważywszy, że Polska ma obecnie dwa święta narodowe 3 Maja i 11 Listopada, chciałbym powtórzyć to, co napisałem na łamach tego samego pisma pięć lat temu:

4 czerwca $1989 \mathrm{r}$. jest niewątpliwie jednym z najważniejszych dni polskiej, ale także i europejskiej historii. Jest dniem, z którego my Polacy, wszyscy Polacy, powinniśmy być dumni. Na lasce marszałka odrodzonego w 1989 r. Senatu wyryte sa właśnie te trzy daty, 3 maja, 11 listopada i 4 czerwca. Ta ostatnia, 4 czerwca, zasługuje w moim mniemaniu na to, aby i ona była świętem narodowym ${ }^{32}$.

prof. dr hab. Marek Ziótkowski

Uniwersytet im. Adama Mickiewicza w Poznaniu

mziolkowski@amu.edu.pl

\title{
ANNUS MIRABILIS 1989 AND ITS LEGACY: FULFILLED PROMISES, SHATTERED ILLUSIONS AND UNEXPECTED RESULTS
}

\author{
Sum mary
}

This paper is an attempt to reconsider the first years of systemic transformations in Poland, or, more precisely, the course of events during democratisation process going on in 1989, and the fundamental problems of the consolidation of democracy in the following years. In a comparative analysis referring to categories used by Samuel P. Huntington in his book: The Third Wave. Democratization in the Late Twentieth Century, it presents the consequences of the fact that democratisation in Poland was achieved by 'transplacement' - joint actions of the government and the opposition, manifested in particular at the Round Table talks. Further the main dilemmas of subsequent years are analysed. These include: the economic and social issues, the problem of the accountability for the past, and the question of how to deal with the praetorians of the former regime. Changes in the social perception of the early transformation period are also described.

${ }^{31}$ J. Kubik, A. Linch, op. cit., s. 28.

32 M. Ziółkowski, W dwudziesta rocznicę wyborów 4 czerwca, „Ruch Prawniczy, Ekonomiczny i Socjologiczny” 71, 2009, z. 4, s. 16. 
Copyright of Journal of Law, Economics and Sociology is the property of Faculty of Law and Administration of Adam Mickiewicz University in Poznan and its content may not be copied or emailed to multiple sites or posted to a listserv without the copyright holder's express written permission. However, users may print, download, or email articles for individual use.

Właścicielem praw autorskich do „Ruchu Prawniczego, Ekonomicznego i Socjologicznego” jest Wydział Prawa i Administracji Uniwersytetu im. Adama Mickiewicza w Poznaniu. Zawartość czasopisma nie może być kopiowana, przesyłana do innych stron internetowych bądź zamieszczana na blogach bez pisemnej zgody wydawcy. Niemniej artykuły można drukować, kopiować lub przesyłać w formie elektronicznej na własny użytek. 